2017-09-03

\title{
Spatializing Climate Justice: Justice Claim Making and Carbon Pricing Controversies in Australia
}

\section{Bailey, Ian}

http://hdl.handle.net/10026.1/8306

\subsection{0/24694452.2017.1293497}

Annals of the American Association of Geographers

Taylor \& Francis (Routledge)

All content in PEARL is protected by copyright law. Author manuscripts are made available in accordance with publisher policies. Please cite only the published version using the details provided on the item record or document. In the absence of an open licence (e.g. Creative Commons), permissions for further reuse of content should be sought from the publisher or author. 
"This is the author's accepted manuscript. The final published version of this work (the version of record) is published by Taylor and Francis in Annals of the Association of American Geographers 2nd January 2018. This work is made available online in accordance with the publisher's policies. Please refer to any applicable terms of use of the publisher."

\title{
Spatializing climate justice: Justice claim-making and carbon-pricing
} controversies in Australia

\section{Ian Bailey}

\section{School of Geography, Earth and Environmental Sciences, Plymouth University}

\begin{abstract}
:
Recent years have seen significant academic attention to conceptualizing climate justice and how its ideas might be mobilized in political debates on climate policy. This article contributes to these debates by advancing two arguments. The first concerns the need for greater examination of how climate justice co-exists and competes with more established political and justice considerations during the negotiation of climate policies. I argue that distinguishing analytically between normative interpretations of climate justice and justice claims made by parties affected by climate change or by mitigation or adaptation policies provides fertile ground for deepening understanding of the multivalent and relational nature of climate justice and confronting challenges to its incorporation into climate responses. The second argument concerns the importance of exploring of how proponents and opponents of climate action strive to develop "spatial anchors" for justice claims to increase their legitimacy in policy debates. Based on analysis of carbon pricing controversies
\end{abstract}


in Australia, the article illustrates how supporters of carbon pricing initiatives stressed international justice issues, while opponents mobilized multi-scalar and multivalent international, national, regional and local justice narratives to gain traction for their arguments. The article concludes by calling for further investigation of the multi-valence of climate justice and of how climate justice might be spatially represented to advance its leverage in political debates on climate policy.

\section{Keywords:}

climate justice, justice claims, carbon pricing, spatial representation, Australia

\section{Introduction}

Justice has formed a major theme in debates on climate change ever since climate issues first began to gain sustained political attention in the 1980s (Meyer and Roser 2010; Bulkeley et al. 2013; Bulkeley, Edwards and Fuller 2014). Over this period, substantial scholarly and political attention has been directed towards conceptualizing the forms of rights, responsibilities, procedures, and distributional outcomes that just responses to climate change might entail and how these might be applied to different issues and social and spatial settings (Backman and Page 2008; Parks and Roberts 2008; Vanderheiden 2008; Roberts and Parks 2009; Bulkeley et al. 2013).

These endeavors have led to appreciable progress in understanding the ethical implications and dilemmas raised by climate justice (Shue 1993; Klinsky and Dowlatabati 2009; Klinsky 2015). However, progress towards integrating justice into climate-related decision-making 
remains faltering. Deeper interrogation of how climate justice is constructed and contested during practical initiatives to mitigate and adapt to climate impacts--where the cross-cutting challenges of climate change for existing political, economic, and social systems are often painfully and acrimoniously manifested--thus remains a priority if climate justice is to progress beyond being an admirable but largely abstract concept (Greer 2014). So far, efforts by climate-justice scholars to address this challenge have been directed mainly at developing normative proposals on how to integrate climate justice into political decisionmaking through ideas such as contraction and convergence and ecological debt repayment (Gardiner 2006; Page 2008; Roberts and Parks 2009; Gardiner 2011). In contrast, detailed empirical studies of how climate justice contends with other, often more established, justice considerations during the negotiation and implementation of climate policies remain relatively scarce. Without greater understanding of the practical relationship between climate justice and climate policy, however, progress in integrating climate justice into political decision-making on climate issues is likely to remain stymied.

This article responds to this agenda by examining how justice is constructed and expressed within debates on national climate policy. National climate politics has been a relatively underexplored area of climate-justice scholarship compared with the international, subnational and city scales (e.g. Parks and Roberts 2008; Peet and Harrison 2012; Bulkeley et al. 2013; Bulkeley, Edwards and Fuller 2014). However, the importance of nation states to climate policy-making and the mediation of climate justice trade-offs suggests that the national politics of climate justice merit more sustained attention. Two main arguments are proposed. The first concerns a need for deeper examination of how climate justice co-exists and competes with more established political and justice considerations within climate 
policy. Preoccupation with conceptualizing or applying climate justice principles risks treating climate justice as somehow removed from other political and justice interests. Allied to this is the importance of developing clearer analytical distinctions between normative interpretations of climate justice (its "rightful" role in climate policy) and justice claims, where individuals or groups use justice arguments sincerely or tactically to gain recognition for their interests (Backman and Page 2008; Klinsky 2015). When examining real-world climate politics, climate-justice scholarship must remain alert to the multiple climate and non-climate justice claims mobilized to gain approval for standpoints that might not enjoy support unless attached to some form of justice claim. As such, the first strand of enquiry focuses on how competing multivalent justice claims, articulating diverse values and preferences, shape debates on climate policy (Fraser 2001; Klinsky 2015).

The second argument concerns the need for further exploration of the tactics used by different actors to gain political legitimacy for their justice claims. Such tactics might include mobilizing widely-accepted discourses, such as stressing technological innovation or carbon markets over lifestyle constraints (Dryzek 2013), utilization of the media (Gavin 2009), or the personalization of issues by identifying climate-related victims and perpetrators (DiFrancesco and Young 2011). Another tactic of keen interest to geographers is the attachment of socio-spatial representations to justice claims--the linking of justice claims to particular groups located in specific places--to enhance the status of claims in debates on climate action (Walker 2009; Klinsky 2015). For instance, corporations might influence climate policy to a degree by highlighting effects on competitiveness but may boost their influence further by aligning their interests with accepted national concerns about economic growth, or with more geographically-rooted issues, such as risks to employment in regions 
that depend on the sector if emissions constraints are imposed. Such spatial anchoring of justice narratives provides a powerful technique for personalizing justice claims and making them more relevant and urgent by affiliating them with politicians' electoral incentives, especially if they are taken up by media outlets and erode public support for climate action (Harrison and Sundstrom 2010).

These themes of multivalent justice claims and their socio-spatial anchoring are explored by examining recent debates on carbon pricing in Australia, where claims about national regional and local socio-economic injustices have been defining features of industry, political and public opposition to carbon pricing. Among the prominent claims have been the injustices of introducing carbon pricing in a minor contributor to global emissions like Australia without action by industrializing countries, and discourses stressing the unfairness of imposing carbon pricing on resource-dependent regions in rural Australia, and on households across the country. These socio-spatial injustice claims overshadowed government arguments about Australia's responsibility to contribute to global mitigation efforts and representations of climate change as a "great moral challenge" (Rudd 2008), and led ultimately to the repeal of carbon pricing in Australia in 2014. Understanding how such socio-spatial justice claims are mobilized and influence climate policy forms a key but largely overlooked dimension of research on justice claim-making in climate politics.

The following section considers how climate justice has been articulated, exploring how climate-related rights, responsibilities, distributional equity, and procedural fairness interact and are underpinned by the recognition of justice claims. Within this discussion, emphasis is placed on distinctions between normative views of climate justice and justice claims 
recognized within debates on climate change, and how claims may be advanced through socio-spatial representations that connect issues and interests to identifiable places and people. The third section outlines the history of carbon pricing in Australia before the fourth section examines how politicians, industry and the media used international, national, regional, and local justice anchorings justice to arouse support or opposition to carbon pricing. The final section explores theoretical and policy implications for understandings of climate justice.

\section{Climate justice in context}

Over the last two decades, scholars across a range of disciplines have explored the principles of climate justice and the justice dilemmas embedded in decision-making on climate policy (Shue 1993; Gardiner 2006; Page 2008; Klinsky and Dowlatabadi 2009; Bulkeley, Edwards and Fuller 2014). While no single justice framework for dividing burdens has emerged (Klinsky, Dowlatabadi and McDaniels 2012), broad agreement exists on the core goals of achieving fairer distributions in rights and responsibilities related to the causes and effects of climate change, spanning mitigation, adaptation, and loss and damages for climate-related harms (Page 2008; Bulkeley et al. 2013). These, however, raise complex questions about temporal, social, and spatial unevenness in greenhouse-gas emissions and vulnerability to the effects of climate change (Hornborg 1998; Gardiner 2006; 2011), while further questions surround procedures for addressing grievances and ensuring representation both for groups affected by climate change and those impacted by climate policies (Lind and Tyler 1988; Shue 1993; Kuehn 2005). MacCoun (2005) and Gross (2007) argue that procedural justice is particularly important where uncertainty exists on what 
constitutes fair aggregate or distributive outcomes to encourage participation by all relevant parties and open debate on the ethical dimensions of climate decision-making ${ }^{1}$.

While rights, responsibilities, representation, and fair procedures provide the conceptual foundations for specifying more detailed justice principles--such as causal responsibility, preferential treatment based on need, and equity of burdens or effort (Singer 2002; Klinsky and Dowlatabadi 2009)-Bulkeley, Edwards and Fuller (2014, 33) also stress the need for investigation of the contexts in which framings of justice are created. Rather than just analysing principles by which climate justice might operate, they call for sustained empirical examination of the political economies, power relations, and opportunity structures influencing how climate justice is conceived, applied and contested. Central to this, they maintain, is recognition, both for groups as rightful stakeholders entitled to be represented in discussions, and for certain arguments to be considered as justifiable (also Gardiner 2006; Grasso 2010; Schlosberg 2012). As Schlosberg (2004) emphasizes, if legitimate groups or concerns are marginalized by those making executive decisions, procedural fairness, and achieving fair outcomes can be critically compromised.

Bulkeley, Edwards and Fuller (2014) conceptualize recognition as forming the critical underpinning of climate rights, responsibilities because of its central role in determining which issues and groups are considered or sidelined in justice debates. They additionally use the metaphor of a prism to emphasize interconnections between the different facets of climate justice and how ideas refract as solutions to justice issues are debated. For instance, recognition of certain rights creates typically creates new responsibilities for other actors that may require new forms of recognition and procedural mechanisms to accommodate 
redistributions of resources (Shue 1993). In most instances, these interactions require negotiation, leading to modified demands and procedures to find acceptable solutions (Page 2008; Parks and Roberts 2008).

This multivalent view of climate justice emphasizing recognition as critical to achieving fair outcomes simultaneously draws attention to distinctions between judgements about what rights, responsibilities, distributions, and procedures should be recognized and those that are accepted in climate debates. Importantly, this shifts the analytical lens from examining recognition chiefly in terms of the ethical and empirical strength of claims towards the capability of individuals and groups to place their values and interests on agendas (Gavin 2009; Walker and Day 2012). Two key considerations arise from this. The first concerns the importance of distinguishing between Rawlsian justice principles and justice claims, where groups seek support for their interests or preferences by framing them as justice concerns (Klinsky 2015). Both entail constructions of distributional and procedural fairness, but focusing on justice claims foregrounds the political reality that responses to climate issues usually impact other interests that enjoy some societal acceptance. These competing claims can take non-commensurable forms and be challenging to adjudicate on ethical grounds (Fiske and Tetlock 1997). Rawls (1972, 340) himself observed that there are often no obvious rules for prioritizing between competing obligations, and doubted "whether a systematic solution formulating useful and practical rules is possible".

Many authors have, nevertheless, explored ethically-defensible ways to address justice dilemmas on climate action. Notable examples include: contraction and convergence that apportions responsibilities through differentiating between luxury and subsistence 
emissions (Shue 1993; 1999); repayment of ecological debts from developed countries to developing countries caused by financially and ecologically unequal trade relations (Roberts and Parks 2009); fault-based and ability-to-pay approaches (Shue 1993); and distributive justice based on equitable burdens or effort (Heyward 2007; Klinsky and Dowlatabadi 2009). Scrutiny of these approaches is beyond the scope of this article. However, all focus on integrating distributive justice into existing political and economic systems rather than empirically examining how power relations within these systems influence how climate justice competes with other justice considerations to shape climate policy. As such, they maintain a normative rather than an explanatory approach to analyzing political deliberations on the ethics of climate action.

The second consideration accordingly focuses on the politics of arbitrating between justice claims. Traditional realist perspectives often downplay the role of justice and emphasize self-interested bargaining and power and resource differentials as determinants of political bargaining within and between nations (Okereke 2010). In national policy contexts, political economy perspectives typically stress access to politicians and officials, finance, media campaigns, and public support as key political resources used by non-government actors to influence decision-makers' incentives (Pralle 2009; Harrison and Sundstrom 2010). More constructivist writers argue, however, that climate policy outcomes cannot be understood solely through the lenses of power and material interests, and stress the devices used to promote standpoints, including the use of discourses to construct interpretations of the nature of environmental problems and the consequences of different policy solutions (Dryzek 2013). Although not the only discursive framing used to steer the normative context of decision-making on climate change (e.g. ideas of ecological modernization), 
justice narratives hold particular potency because of their links with instinctive societal values concerning fair or unfair treatment (Walker and Bulkeley 2006).

While climate justice can be constructed to appeal to many ethical concerns, the main focus in this article is the use of socio-spatial representations to increase the authenticity of justice claims and their connections with other societal priorities. This affiliation of justice claims to identifiable peoples and places resonates with Opotow's theory of moral exclusion, that claims often receive less weight when interpreted as distant, non-essential, and competing with existing deep-core values and preferences (Klinsky, Dowlatabadi and McDaniels 2012). Pinpointing climate victims and perpetrators--such as floodplain populations in Bangladesh and large U.S. fossil-fuel companies--are obvious examples of spatialized justice arguments in climate advocacy. However, drawing boundaries that distance climate impacts and attribution temporally or spatially but invoke immediacy and proximity in the adverse effects of climate policy can equally generate senses of injustice around policies. Industry groups may also counteract being judged as undeserving claimants by projecting their interests as justice considerations affecting more worthy plaintiffs, such as communities and regions that depend on the sector, while giving the justice claim greater geographical rootedness (Hafer and Olson 2003).

Further socio-spatial anchoring of justice claims may invoke justice failings by others. Classic usages of such narratives include: uneven historical contributions to current greenhouse-gas concentrations by the global North and South (Shue 1993); rapid emissions growth among industrializing countries; and the incapacity of low-lying island states to mitigate climate change relative to their vulnerability (Meyer and Roser 2010). Such comparisons can again 
have multiple motivations, but many countries have portrayed climate change as a collective-action problem to stress the unfairness of accepting excessive mitigation burdens (Bulkeley and Newell 2010). Similarly, corporations and governments may advocate level playing fields in the global economy to defend weak climate measures, whilst unequal burden sharing between rural and urban areas may be cited in debates on siting renewableenergy technologies (Cowell, Bristow and Munday 2011).

Multivalence and the socio-spatial anchoring of justice claims thus form critical themes in debates on climate justice. The first is underscored by the reality that, howsoever conceived, climate justice is obliged to compete with other ideas and interests that often incorporate some justice claim, making trade-offs integral to climate decision-making (Klinsky, Dowlatabadi and McDaniels 2012). Similarly, whilst justice claims can utilize multiple framings, the use of socio-spatial representations holds significant potential for legitimating ideas and interests and moving beyond generic principles to situated understandings (Hillman 2006). With this in mind, the following sections summarize the research strategy and the recent history of carbon pricing in Australia before considering how multivalent and spatialized justice claims have influenced policy debates.

\section{Research Strategy}

The first phase of research was conducted in 2010 and analyzed the political arguments and tactics used to debate Australia's first proposed carbon pricing mechanism, the Carbon Pollution Reduction Scheme (CPRS). The second took place in 2015 and focused on debates on the introduction and repeal of the Clean Energy Future Act Carbon Pricing Mechanism (CPM). Each phase involved analysis of official documents, media reporting and 
independent commentaries on carbon pricing (550 and 183 documents in phases one and two respectively), and was complemented by semi-structured interviews with politicians, government officials, and industry, academia, non-government organization, and consultancy representatives involved in developing or analyzing the CPRS and/or CPM. Thirty-one interviews were conducted in phase one, with a further twenty interviews in phase two. A summary of the respondent profile is given in Table 1.

Texts and interview transcripts were subjected to qualitative content analysis, avoiding affixing pre-conceived categories to the arguments mobilized during the carbon-pricing debates; instead categories emerged inductively from the data (Hsieh and Shannon 2005). Categories were then grouped iteratively into related ideas, drawing on recurring themes in accounts and texts to produce researcher descriptions of the main themes arising from the research (Flowerdew and Martin 2005). Although the research explored the broader arguments and tactics used to debate carbon pricing in Australia, justice emerged as a prominent theme, illustrated by frequent uses of terms such as fairness, inequity, and distribution. Numerous references to international, national, regional, and local issues within these arguments in turn prompted further investigation of how justice was discursively and spatially represented carbon pricing opponents and supporters.

\section{Carbon pricing in Australia}

Australia was an early signatory to the Kyoto Protocol but has struggled to take decisive action to reduce its greenhouse-gas emissions. Most analysts attribute this to the political influence of its major extractive and energy-intensive industries and strong political 
competition between the Labor Party, Liberal-National Coalition and the Greens on whether and/or in what form to introduce carbon pricing (Pearse 2009; Burgmann and Baer 2012; Christoff 2013; Crowley 2013; Rootes 2014).

Under Kyoto, Australia committed to restricting its emissions growth to eight percent above 1990 levels by $2008-2012$, but in 2002 the Coalition led by John Howard followed the U.S. in refusing to ratify the Protocol, arguing that it was against Australia's national interest (Crowley 2007; Lawrence 2009). Throughout the 1990s and 2000s, Australian climate policy instead consisted mainly of voluntary measures that avoided binding emissions targets and sanctions, and it was only in 2007 that Howard commissioned a prime ministerial task force to investigate emissions trading in response to pressure from Labor, which was campaigning for carbon pricing in the 2007 federal election campaign (Rootes 2008).

Following a landslide victory, Labor's new prime minister, Kevin Rudd, made Kyoto ratification his government's first official act and began preparing a national emissions trading scheme, the Carbon Pollution Reduction Scheme (CPRS), drawing on recommendations made in the first Garnaut Review commissioned by Rudd to study the effects of climate change on Australia and policy options to reduce Australia's emissions (Garnaut 2008). However, the CPRS model was heavily criticized by the Coalition and industry as damaging to Australia's energy-intensive trade-exposed industries (EITEIs) without comparable measures by trading partners in Asia and North America, and by the Greens for over-generous compensation to EITEls. After the CPRS was rejected by the Senate in August 2009, Rudd sought support for the legislation from the Coalition leader, Malcolm Turnbull, who supported carbon pricing but sought greater assistance for EITEls. 
However, following Turnbull's ousting by carbon-pricing opponent Tony Abbott in December 2009, the CPRS again failed in the Senate and was shelved in 2010 (Bailey et al. 2012; Burgmann and Baer 2012; Crowley 2013).

Following the CPRS's failure and other policy debacles, Rudd was replaced by his deputy, Julia Gillard, in June 2010. Gillard wanted to secure her own mandate and called an election for August 2010. Although carbon pricing remained on the government's agenda, Gillard sought to counteract Coalition successes on the CPRS by promising there would be "no carbon tax under a government I lead". The 2010 election led to a hung parliament, with the government relying on independents for a majority in the House of Representatives. Additionally, the Greens held the balance of power in the Senate, giving the minority government an unexpected opportunity to introduce carbon pricing by renegotiating with the Greens (Crowley 2013).

The Clean Energy Act was adopted in November 2011 despite continued Coalition opposition, creating the Carbon Pricing Mechanism (CPM), an emissions trading scheme covering 300 of Australia's largest polluters. To secure the Greens' support, Gillard introduced an initial fixed price of AUS\$23 per tonne of carbon (approximately $\$ 23.30$, December 2011 exchange rate) between 2012 and 2015 before it moved towards flexible pricing by 2018 (Caripis et al. 2011) $)^{2}$ The fixed price was also intended to give industry certainty about their financial exposure but was portrayed as a thinly-disguised tax that betrayed Gillard's pre-election promises. The Clean Energy Act incorporated further measures to ease burdens on industry and households: a Jobs and Competitiveness Program giving EITEls free allowances; an Energy Security Fund to help energy generators move 
towards low-carbon energy; a Clean Technology Program to promote energy-efficient technologies; and a Clean Energy Household Assistance Package of payments, increased income tax thresholds, and tax benefits for low- and middle-income families (Australian Government 2011).

However, EITEls continued to attack the CPM for damaging competitiveness, while Tony Abbott made a "blood oath" to repeal the carbon tax if elected (Gratton and Wroe 2011). Despite Gillard's replacement as prime minister by her predecessor, Kevin Rudd, in June 2013 and attempts to regain business and voter confidence by announcing that flexible pricing would be introduced a year earlier than planned, the Coalition won the September 2013 election, and in July 2014, Abbott repealed the CPM after securing the support of the Palmer United Party ${ }^{3}$ in the Senate (Rootes 2014).

\section{Justice Claims in Carbon-Pricing Policy in Australia}

Most accounts of Australian climate policy stress structural features of its political economy (the country's fossil-fuel dependence) and the industry lobbying power as explanations for Australia's difficulties in adopting more ambitious mitigation policies (Crowley 2007; Pearse 2009; Rootes 2011; 2014). Although important, these factors provide limited insight on how non-government actors influenced policy, for instance, how industry gained political support for commercial arguments by making them resonate with public or opposition-party concerns. Christoff $(2013,349)$ provides some insight on this by examining how scientific, ethical, economic, technological, political/legal, and everyday life discourses contribute to the constitution of national climate discourse complexes that "frame and discipline climate debate and the articulation of a national climate policy regime". Christoff argues that 
domination of Australia's climate discourse complex by economic narratives has diminished the influence of scientific, ethical, and other discourses ${ }^{4}$ on carbon pricing. However, this still underemphasizes limits on the traction of economic pleading and focuses on aggregate patterns in Australian national climate politics rather than the multiple discourses--including ethical discourses about fair treatment to legitimate commercial arguments--that shape broader discourse complexes, empowering or disempowering actors within national climate-policy debates.

Before analysing how different justice claims were mobilized and spatialized in debates on carbon pricing in Australia, two points should be stressed. First, the analysis seeks to understand how multivalent socio-spatial constructions of justice have shaped Australian debates on carbon pricing, and so avoids value judgements about the claims made. The second concerns the implicit and often unconscious nature of many justice claims. Arguments about the CPRS and CPM frequently contained justice overtones, such as stressing effects on vulnerable groups, but did not employ justice terminology explicitly or in a premeditated way (Klinsky 2015). Alternatively, some actors invoked justice arguments tactically by projecting their political or commercial interests as justice concerns for other parties to elicit greater sympathy without revealing the preferences and judgements upon which the viewpoints in question were based (Howarth 2009; Dryzek 2013).

The core argument within this section is that most opponents of carbon pricing saw the CPRS and CPM as genuinely unjust and/or contrary to their commercial or political interests, but appreciated the fundamental arguments for climate action or the untenability of directly challenging government framings of just climate responses by Australia. Opposition 
consequently centered on highlighting alternative sets of rights, responsibilities, distributive, or procedural issues. Although many such framings drew on older economic discourses about short-term economic security and its allied welfare benefits (Christoff 2013), they propagated multivalent definitions of what fair rights, responsibilities, distributions, and procedures meant within Australia climate policy to contest mainstream government interpretations. A key device in developing these alternative justice framings was to stress the effects of carbon pricing across a range of recognizable spatial jurisdictions within Australia, from the national to the local, to broaden the range and credibility of injustices employed to oppose carbon pricing and to characterize identifiable victims in order to press for recognition of their rights.

\section{International and national justice framings}

Fairness in the distribution of mitigation responsibilities between Australia and other countries has formed a critical theme throughout Australian debates on carbon pricing. The Howard government's dominant narrative centered on drawing normative distinctions between imposing burdens on Australia and the climate responsibilities of other countries. This was expressed forcibly when Howard announced that Australia would not ratify the Kyoto Protocol without comparable commitments by major developing countries because he was not prepared to "be party to something that destroys jobs and destroys the competitiveness of Australian industry" (The Age 2003). Such statements earned Howard the reputation of presiding over a decade of neglect on climate change by hawking justice interpretations that pitched global climate justice against national economic concerns and externalized accountability for his government's reliance on voluntary mitigation (Crowley 2007). 
The Labor government took a starkly different standpoint. Kevin Rudd repeatedly described climate change as: "the greatest moral, economic and social challenge of our time", arguing that an affluent country like Australia had an ethical duty to reduce emissions for well-being of other countries threatened by climate change (Rudd 2008). Similarly, the Garnaut Review stressed that the: "problems of unmitigated climate change will be for all humanity" (Garnaut 2008, 592) while also emphasizing the benefits to Australia's national interest to take action to counter climate risks to the country and to lead in the international marketplace of initiatives to decarbonize the global economy. However, Garnaut did also seek to address distributive issues within Australia by arguing, among other things, for trans-national sectoral agreements for iron and steel, aluminum, chemicals, cement, and paper and pulp to overcome industry relocation and carbon leakage caused by the unequal application of carbon pricing in other countries producing emissions-intensive internationally-traded goods (Garnaut 2008).

Despite such efforts, the CPRS and CPM debates steered towards a more multivalent view of distributive justice, emphasizing short-term economic and social impacts, that diluted the traction of global burden-sharing arguments. Although there was broad support from an early stage for global action to counteract fairness concerns, the CPRS' ambitious design (covering 75 percent of Australian emissions and all six Kyoto greenhouse gases compared with 45 percent coverage of carbon only in Europe) fueled impressions that "Australia was way out in front of other countries" (senior official). International distributive concerns were also fed by early reassurances from the government that "no Australian would be 
worse off under the CPRS". One official argued that this created "unrealistic expectations that hardened industry opposition when the CPRS legislation was released".

Further attempts were made to calm competitiveness concerns during the CPM debate when in 2011 the Gillard government instructed the Productivity Commission to assess the burdens of climate policy in other key economies, although it only analyzed energy generation and transport, and only covered competitive pressures affecting EITEls indirectly (Productivity Commission 2011). Further, the CPM was introduced with the initial fixed price of AUS\$23 (\$23.30) per tonne of $\mathrm{CO}_{2}$-equivalent--at the time at parity with the EU carbon price--to broker a deal with the Greens, and to give certainty about industry's liabilities until the market matured. However, any conciliatory effect from these measures foundered when the EU price collapsed in late 2011. One government official recalled being: “inundated with questions about why Australian companies were paying \$23 per tonne and European companies were paying \$23 per tonne".

Another dimension of international-national injustice narratives was the futility of carbon pricing because of Australia's relatively modest contribution to global emissions. In his autobiography as opposition leader, Tony Abbott argued that Australia only accounted for one percent of global carbon emissions and that China's annual increase in emissions could match Australia's entire carbon output ${ }^{5}$. According to this logic, action by Australia without agreements by industrializing nations would damage industry but make limited difference to global emissions (Abbott 2009). Extending international comparisons beyond competitiveness (and resonating with Garnaut's warnings about carbon leakage) shifted the debate further from Australia's contribution to international environmental and social 
climate justice towards one focused "almost entirely on domestic economic justice" (industry). Furthermore, framing Australia's actions as futile diverted attention from ethical responsibilities Australia might have to reduce emissions and, instead, emphasized only the sacrificial elements of carbon pricing.

Industry groups used further tactics to portray carbon pricing as an unjust contest between Australian and other national interests. These included a further spin on economic arguments stressing the contribution of resource-intensive sectors to Australia's resilience to the 2008-2010 global recession and arguments that "what was good for coal was good for Australia" (official). Similarly, a 2013 Australian Industry Group report avoided contravening broader climate-justice concerns by not opposing carbon pricing outright while still promoting justice arguments about securing a fair deal for Australia. The report expressed support for market-based approaches but raised concerns about the CPM compared with carbon prices in other countries during challenging local and global economic conditions (Australian Industry Group 2013). Industry interviewees also recalled frustration at government negotiators comparing climate policies at a national level. As one industry representative argued:

This approach was no good for understanding competitive pressures. A facility in one Chinese province may not face a carbon price despite there being a regional or national carbon price because there is a lot of shielding and discrepancy between the national and competitive level. Blanket approaches don't work. Equally, imposing annual standard reductions in free 
allowances to EITEls cannot reflect real-life situations and is not responsive to market shifts.

In response, industry associations submitted studies of pressures at the competitive gate comparing the climate policy burdens faced by individual competitor installations to add further dimensions to arguments that Australian companies were being treated unfairly at the international scale (industry).

\section{Regional justice and local mining communities}

While spatial binaries between national and global concerns were a recurring theme in justice claim-making by carbon-pricing opponents, the CPRS and CPM also prompted strident debates on regional justice that led to further targeting and broadening of the justice arguments used to oppose carbon pricing. Much of this focused on securing fair treatment for resource-dependent states like Western Australia and Queensland and mining communities across the country. Among the tactics used was to pinpoint specific regional effects. During the CPM debate, Barnaby Joyce, then Shadow Minister for Regional Australia, Regional Development and Local Government lambasted the government's treatment of regional Australia:

New South Wales [NSW] Treasury figures show that the carbon tax will lead to 31,000 lost jobs in NSW but over 26,000 of these would be in regional Australia, including 18,500 in the Hunter, 7,000 in the Illawarra and 1,000 jobs in the central West... If [the minister] wants to continue his 'embrace the 
challenge' tour of regional Australia he needs to come clean [about] how they are meant to embrace the challenge of fewer employment opportunities... A carbon tax will clearly hurt regional Australia the worst. (Australian Conservative 2011)

Industry lobbying also focused attention on specific communities by spotlighting issues facing individual facilities, including Northern power station in South Australia and the Portland and Kurri Kurri aluminum smelters in Victoria and New South Wales (industry and regulator). Although there was no suggestion this tactic was used cynically, it contributed to the diversity of justice arguments used by personalizing the impacts of carbon pricing to generate "victims and villains" stories. Because of regional concentrations in coal mining, the coal sector was particularly active in staking regional injustice claims (official), while regulators recalled energy companies threatening power failures in major cities because: "the carbon price would trigger a huge asset write-off on coal-based assets and a number of generators could go bankrupt".

The latter example offers an interesting demonstration of the growing multivalence of justice claim-making brought about by drawing "innocent bystanders" into the carbonpricing debate through the idea that it would negatively affect every aspect of people's lives in cities like Melbourne that rely on coal-fired electricity. Interviewees argued that portrayals of the government failing to protect coal-mining regions and power supplies did not reflect the intensity of consultations with industry or the sophisticated measures introduced to address distributive issues (see Behm (2015) for an insider account of consultations on the CPM). One academic nevertheless noted that a belief among officials 
that a market instrument would automatically resolve distributive problems caused them to underestimate subnational issues. A senior ex-official and government advisor further recalled that, following consultations, the government often: "thanked associations then closed the door to focus on policy development". This led to industry feeling marginalized from final decision-making because of the government's preoccupation with gaining support from key political partners. As one consultant put it: "there was the odd brown-bag discussion, but the government didn't see business as critical in getting the legislation through"... and this "aggravated industry anger towards the CPM where distributive issues remained unresolved". In contrast, a senior negotiator argued that: "whatever we did, some sectors always tabled further demands and used Tony Abbott's attacks on carbon pricing opportunistically to gain leverage".

One crucial feature enabling regional justice arguments to feature so prominently was that, unlike the EU ETS negotiations, the CPRS and CPM debates took place in the full media and political glare. One consultant argued that because that industry: "felt disenfranchised from decision-making, they used the media to present their issues as general voter concerns and to lobby individual electorates". This tactic again proved potent because it played on longstanding resentment about the neglect of mining and other resource-dependent towns in regional Australia by political elites in Canberra, Sydney, and Melbourne (Botterill 2006; see Peet and Harrison 2012 for similar portrayals of urban-rural political dynamics in British Columbia). In this case, legacies of neglect found two expressions: uneven impacts of carbon pricing on regional households that experience higher car dependence, longer travel distances and more extreme climates; and direct challenges to livelihoods from the possible contraction or closure of major employers in the resources sector. The Australian 
newspaper provided inflammatory reporting of this issue in a 2011 study for the Australian Coal Association (ACIL Tasman 2011):

Explosive economic modelling warns that the carbon tax could force eight black coalmines to close, costing nearly 3000 jobs in regional NSW and more than 1100 jobs in Queensland in its first three years... Independent modelling commissioned by the Australian Coal Association warns that early mine closures could reach 18 within nine years... ACIL Tasman estimates that between 22,700 and 31,020 man-years of jobs will be forgone... Mr Hillman [executive director of the ACA] said: "These are real jobs, supporting real families in regional Australia". (The Australian 2011, emphasis added).

Bacon and Nash (2012) note that media coverage of the carbon-pricing debate exhibited journalistic endorsement across all newspapers of the national and regional economic benefits of coal mining and electricity generation but marked differences in reporting of the sectors' climate impacts, a perception illustrated by coverage of impacts on marginal electorates, such as Townsville in Queensland, where mining provides around one-third of employment (Speck 2010). Contrasting assessments by the Climate Institute (2011) and other pro-carbon pricing groups, meanwhile, contributed to public perceptions of injustice surrounding the CPRS and CPM from alternative directions, as offering unjust compensation to EITEIs (academic). The characterization of issues and groups were recalled by one regulator involved in media communications: 
When the CPM came out, it was terrible. We were forced into being very defensive; the media was taking a tabloid approach on cost and the idea that the prime minister lied about not introducing a carbon tax. There were also constant comparisons with actions elsewhere, this myth that Australia was leading the world and it was very difficult to cut through these arguments. But, if we didn't engage with the media, the CPM would be even attacked even more, but however we tried, we had 'shock jocks' [populist radio commentators] and other press on our backs.

One issue that struggled to command political attention because of such reporting, despite repeated efforts, was the justice implications of Australia's vulnerability to climate impacts. The 2008 and 2011 Garnaut Reviews both placed strong emphasis on regional and national climate impacts to strengthen the case for carbon pricing, while Bureau of Meteorology reports routinely stressed threats to water availability, infrastructure, energy systems, urban areas, and terrestrial and marine ecosystems, including the Great Barrier Reef (Cleugh et al. 2011). Although this characterized climate change as an issue worthy of attention and certain areas as under threat, it did not translate into robust public support for carbon pricing (Pietsch and McAllister 2010), not least because of disputing by industry and opposition leaders of links between individual events and climate trends (senior official). As Prime Minister, Tony Abbott characterized reports linking the 2013 Sydney bushfires to climate change as "hogwash", claiming Australia had always experienced fires and floods (The Guardian 2013a), a view supported by environment minister Greg Hunt (consultant). 
Such questioning of links between extreme events and climate change and the framing of carbon pricing as conflicting with national and local economic justice arguably compounded the domination of Australia's climate discourse complex by economic discursive fields that emphasized resource-led short-term growth (Christoff 2013), and forced the Garnaut Review team and other carbon-pricing proponents into defending carbon pricing on these grounds rather than the longer-term economic and social implications of climate change (consultant). Shifting the debate into this economic terrain, meanwhile, further enabled carbon-pricing opponents to emphasize distributive justice by fashioning geographically personalized non-climate justice narratives (Kurz, Augoustinos and Crabb 2010).

\section{Justice for households}

A final arena of justice claim-making in Australian carbon-pricing debates concerned implications for households. John Howard again set the tone for this discussion in 2006 by contrasting equivocal acceptance of climate science with emphasizing a broad range of nonclimate justice concerns: the "enormous burden to be carried by consumers through much higher electricity prices, higher petrol prices, falls in GDP, of too dramatic an imposition of what you might call an anti-greenhouse policy." (Australian Broadcasting Corporation 2006). The characterization of carbon pricing as a multi-pronged injustice against working Australians was intensified by Abbott, who branded the CPRS "a great big tax on everything" and declared the 2013 election a referendum on the carbon tax (academic). As was noted earlier, the political capital gained by these attacks forced Julia Gillard to assert during the 2010 election campaign that there would be: "No carbon tax under a government I lead", though she maintained throughout that she would introduce carbon pricing (Rootes 2014). 
In fact, the Gillard government worked energetically to address the CPM's impact on households. One senior official described how the department was instructed:

to track every form of household category to analyze the effects of different carbon prices and their translation into electricity prices, and to scour every element of the tax system to identify where and how households could be assisted so the CPM did not create a financial burden.

One independent expert described the Household Assistance Package's treatment of equity as "outstanding" and "a wonderful analysis". The official nevertheless conceded that:

the package failed because the government decided not to link it to the CPM because the CPM was so unpopular and instead presented the package as a tax gift. It was a political decision to benefit the minority government, but in hindsight the government missed the opportunity to steer public debate towards climate change and the basic reason for carbon pricing.

In addition to damage inflicted by Gillard's decision to introduce an initial fixed price on carbon of AUD \$23 per tonne caused by the collapse of EU carbon prices, officials and regulators also recalled several unrelated issues becoming conflated within the growing and increasingly multi-issue narrative of injustice surrounding the CPM. These included the global financial crisis and increases in electricity prices caused by overinvestment in energy infrastructure. Neither was connected to the CPM but coincidences in timing enabled anticarbon tax campaigners to stir up further unfairness narratives. In addition to Abbott's 
sloganeering on the "tax on everything" and Gillard's carbon tax "lie", regulators noted provocative remarks by Barnaby Joyce that the Australian Sunday roast would cost AUD\$100 (US\$101, December 2011), and pledges by the Palmer United Party, a key partner in repealing the CPM in 2014, to refund the tax that it claimed was destroying Australian families (Palmer United Party 2013).

Although justice claim-making on behalf of households might be categorized as a social rather than a spatial issue, it has distinctive spatial implications under Australia's compulsory preferential voting system. This requires voters in each electorate to rank candidates in preference order; if no candidate gains over 50 percent of first preferences, the candidate with the fewest votes is excluded and their votes are reallocated to second preferences until someone achieves a majority. Supporters argue that the system represents all citizens' views, but opponents argue that it forces voters to support nonpreferred candidates and increases safe electorates because voters often rank their nonpreferred major party low in their preferences (Evans 2006; Fowler 2013). It also encourages parties to court popularity across a range of issues to maximize preferences gained from eliminations rather than taking a strong stand on individual issues. Compulsory voting also incentivizes targeting of voters with limited interest in politics in marginal electorates rather than the majority whose voting behaviour is guaranteed. The 2013 election saw focused campaigning in the Western Sydney, Melbourne, and Brisbane suburbs, often accompanied by locally-directed expenditure pledges (The Guardian 2013b). Although the government sought to defuse Abbott's attacks by announcing the early introduction of flexible pricing, Abbott claimed this merely replaced an unjust fixed tax with an unfair variable one (Rootes 2014). 
In summary, developing multiple lines of justice argumentation, especially focusing on the short-term economic and social costs of climate action, and the spatialization of these claims towards discrete socio-spatial scales and locations proved a highly effective weapon in undermining carbon pricing in Australia despite assessments that the impacts of the CPM were substantially mitigated by industry and householder assistance (Meng, Siriwardana and McNeill 2013). In particular, pitching injustice claims about carbon pricing within specified national, regional and local boundaries enabled CPM opponents to reach multiple audiences, influence how issues and groups were characterized, and outmaneuver government attempts to frame carbon pricing as a general global-justice and nationalconscience issue. Interestingly, claims about injustices created by the CPM appeared to gain greater political traction than tangible measures to address distributive issues. Most assessments suggest the government provided innovative measures to ameliorate the CPM's effects on households and regionally concentrated industries. However, its unwillingness to stress links between the household package and climate action underscores the importance of messaging framing and claim-making within debates on climate policy. The government's failure to generate momentum behind the distributional impacts of climate change on Australia can be again attributed chiefly to the Coalition's capacity to dispute links between individual events and human impacts in order to recharacterize which issues and groups deserved and did not warrant recognition. Additionally, casting doubt on Australia's ability to make a difference to global emissions proved useful in magnifying the injustice of imposing burdens on Australian regions and households, whilst simultaneously projecting justice responsibilities towards other countries where action deficits could be identified within the international climate negotiations. 


\section{Conclusions}

Australia has witnessed a highly adversarial debate on carbon pricing over the last decade (Rootes $2011 ; 2014)$. Although the extent to which this has extended beyond parliamentary and business circles into the media and public debate makes Australia an extreme case, even compared with the U.S., it illustrates many difficulties that can encircle national debates on the justice dimensions of climate policy. Australia's stalling in introducing decisive policies to reduce its greenhouse-gas emissions is commonly attributed to its fossilfuel dependency, the lobbying power of resource-intensive industries, and self-interested politics (Pearse 2010; Rootes 2011; Crowley 2013). However, these interpretive lenses provide only a partial insight on how such national and commercial interests gain political traction in the face of scientific, international, and ethical pressure for climate action. Justice perspectives do not hold a monopoly on explanations for the introduction or failure of policies. However, most climate debates involve some discussion of rights, responsibilities, and distributions. As such, critical analysis of justice narratives provides instructive comparative lessons on how perceptions of fairness influence climate agenda setting (Klinsky 2015).

This article has advanced two main arguments. The first concerns the need for sustained attention to how climate justice interacts with other forms of justice claim within climate politics. Whilst conceptualizing the principles and parameters of climate justice and how it might be integrated into international negotiations and individual climate initiatives is vital for clarifying the rights, responsibilities, distributions, and procedures affected by climate change, scholars must also engage actively with alternative justice discourses surrounding 
this topic to help understand and shape trade-offs between climate and non-climate justice claims in climate policy (Christoff 2013). In Australia, the interweaving of multiple justice arguments around climate impacts and the economic and social impacts of carbon pricing was an important contributor to the repeal of the CPM and underscores the reality that different voices appeal to diverse ethical bases and audiences to influence what are accepted as legitimate or unjust responses to climate change (Walker and Shove 2007).

Recent work conceptualizing climate justice has stressed its multivalent and evolving character and that: "the politics and practices of... climate change interventions are constantly engaging with and refracting the idea of justice," (Bulkeley, Edwards and Fuller 2014, 31). However, the Australian case suggests the need to consider two overlapping but distinctive circuits of refraction. The first concerns how climate justice responsibilities, distributions, and procedures interact internally to produce new understandings of the concept and its implications. The second concerns how each component of climate justice interacts with other justice claims, such as freedom of choice and economic livelihoods. In the Australian carbon-pricing debates, few actors openly contested rights of protection from climate impacts, but many still opposed carbon pricing on alternative justice grounds. This more multivalent view of how justice is framed in climate politics accentuates the need to understand each element of justice as a complex of climate and non-climate justice considerations, each with its own dilemmas and trade-offs in how justice principles and claims are prioritized, rather than viewing each solely in terms of climate rights, responsibilities, distributions and procedures (Rawls 1972; Klinsky, Dowlatabadi and McDaniels 2012). Although this further complicates analysis of climate justice by incorporating non-climate justice considerations alongside climate justice, it also creates 
productive spaces to explore more deeply how conflicts between different sets of rights, responsibilities, distributions, and procedures are mediated during the negotiation of climate initiatives.

This emphasis on climate justice claim-making also foregrounds important distinctions between normative ideas about what claims should be recognized and claimants' capacity to gain recognition for themselves and their arguments (Schlosberg 2004). While all protagonists in the Australian carbon-pricing debate sought to maintain the moral high ground by employing justice-related argumentation, gaining political traction was often determined as much by proficiency in securing recognition as by the substance of arguments (Christoff 2013). In this case, broadening the range of issues deemed to merit consideration and populist sentiments about unfair taxation ${ }^{6}$ on households and tradeexposed industries gained greater media exposure and recognition than practical packages to address distributive issues. In addition to underscoring the importance of recognition in climate justice debates, such instances raise questions about ensuring procedural fairness where gaining recognition is determined by capabilities rather than normative arguments (Gross 2007).

The second argument concerns the attachment of socio-spatial representations to justice claims as a device to enhance recognition by aligning arguments with identifiable places and peoples. Routledge $(2011,384)$ argues that climate activists might use such spatial framings to draw out "translocal climate justice solidarities" between peoples experiencing climate injustices. However, the Australian carbon-pricing experiences equally illustrated the spatialization of justice claims as a framing device to highlight genuine concerns about 
regional impacts and to pursue commercial or political interests "in the shadow" of fairness claims (Boykoff 2008). Both sides in the debate used socio-spatial justice representations to strengthen their arguments. However, carbon-pricing opponents proved more skillful in generating spatially- and socially-recognizable discourses about distributional impacts on households and communities in regional Australia, and in constructing selective portrayals of national interests vis-à-vis those of other nations. In contrast, carbon-pricing advocates relied on responsibilities-based representations of Australia's international duty to reduce emissions, and failed to engage in sustained communication about regional climate impacts in Australia.

Beyond conceptual contributions, the findings hold important practical implications for research on the justice dimensions of climate policy. In particular, they highlight questions about how to mediate climate and alternative justice claims. An obvious first step is greater engagement with the multivalent and relational nature of climate justice vis-à-vis more established justice matrices. Allied to this is careful unpacking of the discourses and tactics used to promote both climate and alternative justice claims, to understand--and where necessary challenge--the processes through which different justice claims gain recognition (Bulkeley, Edwards and Fuller 2014).

A second priority is further examination of how the justice arguments favoring climate action might be spatialized more effectively. Evidence from Australia suggests that framings of climate change as a long-term, international issue often fail to persuade key audiences compared with more localized and economically-focused narratives. One more spatially nuanced framing gaining momentum in Australia highlights energy justice as a way of 
connecting global climate concerns to multi-scalar concerns about the financial, environmental, and health implications of energy production. Pearse (2015) describes how activists have shifted attention from carbon pricing towards new coal power projects in Victoria, Queensland, and Western Australia, using community campaigns to stress the protection of local landscapes and communities from blanket mining alongside broader climate themes. Parallel campaigns by Beyond Zero Emissions have involved nationwide tours promoting and large- and small-scale renewable-energy projects with local communities and decision-makers aimed at achieving 100 percent renewable energy across the electricity grid (Pearse 2015). Other spatially-focused justice narratives might target geographically-specific climate-related threats, for instance to water availability for agricultural communities in Australia's Murray-Darling Basin, or widely-publicized threats to the Great Barrier Reef from the expansion of the Abbot Point deepwater port for coal exports (Bettini 2013). A further option is more spatialized portrayals of the justice cobenefits of climate action, such as improved health and transportation systems, to connect them compellingly to specific places and personal priorities (Chapman 2015).

These are just a few options for giving climate justice greater geographical rootedness in climate policy, but there are doubtless many others. Either way, deeper embedding of climate justice into political decision-making remains a critical challenge, and further exploration of the multivalence and socio-spatial dimensions of justice claim-making remains an important frontier for research on climate justice. 


\section{Notes}

${ }^{1}$ However, Skitka, Winquist and Hutchinson (2003) argue that if a group is convinced that outcomes are moral or immoral, procedural fairness may be less important than outcomes due to the strength of a priori convictions.

${ }^{2}$ The main obstacle to negotiations was that the Greens regarded the government's target to reduce emissions to 5 percent below 2000 levels by 2020 as under-ambitious. Raising the target was problematic, however, because it was supported by the Coalition and industry. A compromise was reached whereby the Greens supported an initial fixed price of \$23 to create incentives for emissions reduction in return for agreement that Australia's emissions targets would be reviewed by the independent Climate Change Authority.

${ }^{3}$ Formed by Clive Palmer, in 2013 with an agenda to repeal the CPM and restore Australia's economic prosperity.

${ }^{4}$ Economics is, of course, a form of ethical argumentation with its own normative compasses for deciding justifiable courses of action. However, the distinction Christoff draws is between: (i) ethical discourses centered on climate ethics and the normative appropriateness of different mitigation and adaptation solutions; and (ii) economic discourses about efficiency, welfare, development, and modernization, ranging from older economic discourses supporting resource-centered growth that entail weak valuations of nature and higher future discounting and bias cost-benefit calculations towards short-term economic security, employment, investment and welfare, to newer economic discourses that incorporate the future costs of climate change. Christoff's ethical and economic discourses thus both contain normative standpoints but contest what matters when judging 
the justice of different approaches to cost-sharing the burdens of climate impacts, mitigation and adaptation. I am grateful to one anonymous referee for this point.

${ }^{5}$ Australia's emissions are estimated to be 1.4 percent of the global total, but this figure excludes emissions from coal exports because these are attributed to countries where greenhouse gases are emitted for energy generation under Kyoto accounting rules.

${ }^{6}$ As Peet and Harrison (2012) note, the term tax often invokes negative feelings among voters, while even revenue-neutral taxes is contentious either because voters disbelieve that environmental taxes can accomplish anything without imposing penalties. 


\section{References}

Abbott, T. 2009. Battlelines. Carlton, VIC: Melbourne University Press.

ACIL Tasman. 2011. Impact of carbon price on black coal mining: Updated analysis of alternative carbon price scenarios. Brisbane: ACIL Tasman, https://www.qrc.org.au/ dbase upl/ACIL\%20Tasman\%20report\%202,\%2030.9.11.pdf (last accessed 12 December 2014].

Australian Broadcasting Corporation. 2006. John Howard interview: Energy. http://www.abc.net.au/4corners/content/2006/s1738726.htm (last accessed 20 May 2015).

Australian Conservative. 2011. Carbon tax to hit regional Australia the hardest.

http://australianconservative.com/2011/08/carbon-tax-to-hit-regional-australia-thehardest/ (last accessed 20 May 2015).

Australian Government. 2011. Securing a clean energy future: The Australian Government's climate change plan. Commonwealth of Australia: Canberra.

Australian Industry Group. 2013. Ai Group survey: Business pricing responses to Australia's carbon tax, the first six months.

http://www.aigroup.com.au/portal/binary/com.epicentric.contentmanagement.servlet.Con tentDeliveryServlet/LIVE CONTENT/Publications/Reports/2013/Economics/Carbon price i mpacts Jan_2013.pdf (last accessed 2 October 2015).

Bacon, W. and C. Nash. 2012. Playing the media game. Journalism Studies 13 (2): 243-58. 
Bailey, I., I. MacGill, R. Passey and H. Compston. 2012. The fall (and rise) of carbon pricing in Australia: A political strategy analysis of the carbon pollution reduction scheme.

Environmental Politics 21 (5): 691-711.

Beckman, L. and E. Page. 2008. Perspectives on justice, democracy and global climate change. Environmental Politics 17 (4): 527-35.

Behm, A. 2015, No Minister: So you want to be a chief of staff? Melbourne: Melbourne University Press.

Botterill, L. 2006. Soap operas, cenotaphs and sacred cows: countrymindedness and rural policy debate. Public Policy 1 (1): 23-36.

Boykoff, M. 2008. The cultural politics of climate change discourse in UK tabloids. Political Geography 27 (5): 549-69.

Büchs, M., N. Bardsley and S. Duwe. 2011. Who bears the brunt? Distributional effects of climate change mitigation policies. Critical Social Policy 31 (2): 285-307.

Bulkeley, H. and P. Newell. 2010. Governing climate change. Abingdon: Routledge.

Bulkeley, H., J. Carmin, V. Castán Broto, G. Edwards and S. Fuller. 2013. Climate justice and global cities: Mapping the emerging discourses. Global Environmental Change 23 (5): 91425.

Bulkeley, H., G. Edwards and S. Fuller. 2014. Contesting climate justice in the city: Examining politics and practice in urban climate change experiments. Global Environmental Change 25: $31-40$. 
Burgmann, V. and H. A. Baer. 2012. Climate politics and the climate movement in Australia. Melbourne: Melbourne University Press.

Caripis, L., J. Peel, L. Godden and R. Keenan. 2011. Australia's carbon pricing mechanism. Climate Law 2 (4): 583-603.

Chapman, R. 2015. Time of useful consciousness: acting urgently on climate change. Wellington: Bridget Williams Books.

Christoff, P. 2013. Climate discourse complexes, national climate regimes and Australian climate policy. Australian Journal of Politics and History 59 (3): 349-67.

Cleugh, H., M. Stafford Smith, M. Battaglia and P. Graham. 2011. Climate change. Collongwood, VIA: CSIRO Publishing.

Climate Institute. 2011. Jobs growth in a low pollution economy. http://www.climateinstitute.org.au/verve/ resources/tci joblosses mythbuster august201 1.pdf (last accessed 12 December 2014).

Cowell, R., G. Bristow and M. Munday. 2011. Acceptance, acceptability and environmental justice: The role of community benefits in wind energy development. Journal of Environmental Planning and Management 54 (4): 539-57.

Crowley, K. 2007. Is Australia faking it? The Kyoto Protocol and the greenhouse policy challenge. Global Environmental Politics 7 (4): 118-39.

- - . 2013. Pricing carbon: The politics of climate policy in Australia. Wiley Interdisciplinary Reviews: Climate Change 4 (6): 603-13. 
DiFrancesco, D. A. and N. Young. 2011. Seeing climate change: The visual construction of global warming in Canadian national print media. Cultural Geographies 18 (4): 517-36.

Dryzek, J. 2013. The Politics of the Earth: Environmental discourses (third edition). Oxford: Oxford University Press.

Evans, T. 2006. Compulsory voting in Australia. Australian Electoral Commission. http://emailfooter.aec.gov.au/About AEC/Publications/voting/files/compulsory-voting.pdf (last accessed 26 May 2015).

Fiske, A. P. and P. Tetlock. 1997. Taboo trade-offs: Reactions to transactions that transgress the spheres of justice. Political Psychology 18 (2): 255-97.

Flowerdew, R. and Martin, D. 2005. Methods in Human Geography: A Guide for Students doing a Research Project. Abingdon: Routledge.

Fowler, A. 2013. Electoral and policy consequences of voter turnout: Evidence from compulsory voting in Australia. Quarterly Journal of Political Science 8 (2): 159-82.

Fraser, N. 2001. Recognition with ethics? Theory, Culture and Society 18 (2-3): 21-42.

Gardiner, S.M. 2006. A perfect moral storm: climate change, intergenerational ethics and the problem of moral corruption. Environmental Values 15 (3): 397-413.

- - . 2011. A Perfect Moral Storm: The ethical tragedy of climate change. Oxford: Oxford University Press.

Garnaut, R. 2008. The Garnaut Climate Change Review: Final report. Cambridge, UK: Cambridge University Press. 
Garnaut, R. 2011. The Garnaut Review 2011: Australia in the global response to climate change. Cambridge, UK: Cambridge University Press.

Gavin, N. 2009. Addressing climate change: A media perspective. Environmental Politics 18 (5): 765-80.

Grasso, M. 2010. An ethical approach to climate adaptation finance. Global Environmental Change 20 (1): 74-81.

Gratton, M. and M. Wroe. 2011. Abbott's blood oath to repeal carbon tax. Sydney Morning Herald 13 October 2011 http://www.smh.com.au/national/abbotts-blood-oath-to-repealcarbon-tax-20111012-1|l80.html (last accessed 3 June 2014).

Greer, A. 2014. Towards climate justice? A critical reflection on legal subjectivity and climate injustice: Warning signals, patterned hierarchies, directions for future law and policy. Journal of Human Rights and the Environment 5 (0): 103-33.

Gross, C. 2007. Community perspectives of wind energy in Australia: The application of a justice and community fairness framework to increase social acceptance. Energy Policy 35 (5): 2727-36.

Giljum, S. and N. Eisenmenger. 2004. North-south trade and the distribution of environmental goods and burdens. A biophysical perspective. Journal of Environment and Development 13 (1): 73-100.

Hafer, C. and J. Olson. 2003. An analysis of empirical research on the scope of justice. Personality and Social Psychology Review 7 (4): 311-23. 
Heyward, M. 2007. Equity and international climate change negotiations: a matter of perspective. Climate Policy 7 (6): 518-34.

Harrison, K. and L. M. Sundstrom. 2010. Conclusion: The comparative politics of climate change. In Global commons, domestic decisions: The comparative politics of climate change, eds K. Harrison and L. M. Sundstrom, 261-90. Cambridge, MA: MIT Press.

Hillman, M. 2006. Situated justice in environmental decision-making: Lessons from river management in Southeastern Australia. Geoforum 37 (5): 695-707.

Hornborg, A. 1998. Towards an ecological theory of unequal exchange: articulating world system theory and ecological economics. Ecological Economics 25 (1): 127-136.

Howarth, D. 2009. Power, discourse and policy: Articulating a hegemonic approach to critical policy studies. Critical Policy Studies 3 (3-4): 309-35.

Hsieh, H.F. and Shannon, S.E. 2005. Three approaches to qualitative content analysis. Qualitative Health Research 15 (9): 1277-88.

Klinsky, S. 2015. Justice and boundary setting in greenhouse gas cap and trade policy: A case study of the Western Climate Initiative. Annals of the Association of American Geographers 105 (1): 105-22.

Klinsky, S. and H. Dowlatabadi. 2009. Conceptualizations of justice in climate policy. Climate Policy 9 (1): 88-108.

Klinsky, S., H. Dowlatabadi and T. McDaniels. 2012. Comparing public rationales for justice trade-offs in mitigation and adaptation climate policy dilemmas. Global Environmental Change 22 (4): 862-76. 
Kuehn, R. 2000. A taxonomy of environmental justice. Environmental Law Reporter 30 (9): 10681-703.

Kurz, T., M. Augoustinos and S. Crabb. 2010. Contesting the 'national interest' and maintaining 'our lifestyle': A discursive analysis of political rhetoric around climate change. British Journal of Social Psychology 49 (3): 601-25.

Lawrence, P. 2009. Australian climate policy and the Asia Pacific Partnership on Clean Development and Climate (APP). From Howard to Rudd: Continuity or change? International Environmental Agreements 9 (3): 281-99.

Lind, A. and T. Tyler. 1988. The social psychology of procedural justice. New York: Plenum Press.

MacCoun, R. 2005. Voice, control and belonging: The double-edged sword of procedural fairness. Annual Review of Law and Social Science 1 (1): 171-201.

Meng, S., M. Siriwardana and J. McNeill. 2013. The environmental and economic impact of the carbon tax in Australia. Environmental and Resource Economics 54 (3): 313-32.

Meyer, L. and D. Roser. 2010. Climate justice and historical emissions. Critical Review of International Social and Political Philosophy 13 (1): 229-53.

Okereke, C. 2010. Climate justice and the international regime. Wiley Interdisciplinary Reviews: Climate Change 1 (3): 462-74.

Page, E. 2008. Distributing the burdens of climate change. Environmental Politics 17 (4): $556-75$. 
Palmer United Party. 2013. National Policy. http://palmerunited.com/wp-

content/uploads/2013/07/Palmer-United-Party-National-Policy-16MAY2013.pdf (last accessed 20 May 2015).

Parks, B. and J. T. Roberts. 2008. Inequality and the global climate regime: Breaking the north-south impasse. Cambridge Review of International Affairs 21 (4): 621-48.

Pearse, G. 2009. Quarry vision: coal, climate change and the end of the resources boom. Quarterly Essay 33: 1-140.

Pearse, R. 2015. The political economy of carbon pricing in Australia: Contestation, the state and governance failure. Unpublished PhD thesis, University of New South Wales.

Peet, C. and Harrison, K. 2012. Historical legacies and policy reform: Diverse regional reactions to British Columbia's carbon tax. BC Studies 173 (Spring 2012): 97-122.

Pietsch, J. and McAllister, I. 2010. 'A diabolical challenge': Public opinion and climate change policy in Australia. Environmental Politics 19 (2): 217-36.

Pralle, S. 2009. Agenda-setting and climate change. Environmental Politics 18 (5): 781-99.

Productivity Commission. 2011. Carbon emission policies in key economies. Melbourne:

Productivity Commission.

http://www.pc.gov.au/ data/assets/pdf file/0003/109830/carbon-prices.pdf (last accessed 1 October 2015).

Rawls, J. 1972. A theory of justice. Oxford: Oxford University Press. 
Roberts, T. and B.C. Parks. 2009. Ecologically unequal exchange, ecological debt, and climate justice: the history and implications of three related ideas for a new social movement. International Journal of Comparative Sociology 50 (3-4): 385-409.

Rootes, C. 2011. Denied, deferred, triumphant? Climate change, carbon trading and the Greens in the Australian federal election of 21 August 2010. Environmental Politics 20 (3): 410-17.

- - . 2014. A referendum on the carbon tax? The 2013 Australian election, the Greens, and the environment. Environmental Politics 23 (1): 166-73.

Routledge, P. 2011. Translocal climate justice solidarities. In The Oxford handbook of climate change and society, ed. J. Dryzek, R. Norgaard and D. Schlosberg, 384-98. Oxford: Oxford University Press.

Rudd, K. 2008. Building a better world together: Speech at Kyoto University 9 June 2008. http://pmtranscripts.dpmc.gov.au/release/transcript-15955 (last accessed 2 October 2015).

Schlosberg, D. 2004. Reconceiving environmental justice: Global movements and political theories. Environmental Politics 13 (3): 517-40.

- - - 2012. Climate justice and capabilities: A framework for adaptation policy. Ethics and International Affairs 26 (4): 445-61.

Shue, H. 1993. Subsistence emissions and luxury emissions. Law and Policy 15 (1): 39-59.

-- - 1999. Global environment and international inequality. International Affairs 75 (3): 531-45. 
Singer, P. 2002. One world: the ethics of globalization. New Haven, CT: Yale University Press.

Speck, D. 2010. A hot topic? Climate change mitigation policies, politics, and the media in Australia. Human Ecology Review 17 (2): 125-34.

Skitka, L., J. Winquist and S. Hutchinson. 2003. Are outcome fairness and outcome favourability distinguishable psychological constructs? A meta-analytic review. Social Justice Research 16 (4): 309-41.

The Age. 2003. I won't ratify Kyoto Protocol: PM. 2 December 2003, http://www.theage.com.au/articles/2003/12/02/1070127416251.html (last accessed 5 December 2014).

The Australian. 2011. Carbon tax 'will cost 4000 coal jobs'. http://www.theaustralian.com.au/national-affairs/carbon-tax-will-cost-4000-coaljobs/story-fn59niix-1226074538742 (last accessed 12 December 2014).

The Guardian. 2013a. Missing logic of Australian prime minister's denial of climate change link to bushfires. http://www.theguardian.com/environment/planetoz/2013/oct/29/climate-change-bushfires-smoking-denial-tony-abbott (last accessed 12 December 2014).

The Guardian. 2013b. Campaign watch: 2013 Australian election interactive map. http://www.theguardian.com/world/datablog/interactive/2013/aug/19/australian-electioncampaign-map (last accessed 12 December 2014).

Vanderheiden, S. 2008. Atmospheric justice: A political theory of climate change. Oxford: Oxford University Press. 
Walker, G. 2009. Beyond distribution and proximity: Exploring the multiple spatialities of environmental justice. Antipode 41 (4): 614-36.

Walker, G. and H. Bulkeley. 2006. Geographies of environmental justice. Geoforum 37 (5): 655-659.

Walker, G. and R. Day. 2012. Fuel poverty as injustice: Integrating distribution, recognition and procedure in the struggle for affordable warmth. Energy Policy 49: 69-75.

Walker, G. and E. Shove. 2007. Ambivalence, sustainability and the governance of sociotechnical transitions. Journal of Environmental Policy and Planning 9 (3): 213-25.

IAN BAILEY is Professor in the School of Geography, Earth and Environmental Sciences at Plymouth University, Plymouth, UK. E-mail: ian.bailey@plymouth.ac.uk. His research interests include climate and energy politics and the social dimensions of sustainability. 
